\title{
Perbandingan status gizi dan karies gigi pada murid SD Islam Athirah dan SD Bangkala III Makassar
}

\author{
Nurlindah Hamrun,* Mughny Rathi** \\ *Bagian Biologi Oral \\ **Mahasiswa tahap profesi \\ Fakultas Kedokteran Gigi Universitas Hasanuddin \\ Makassar, Indonesia
}

\begin{abstract}
Economic status has an impact in life aspect, including nutrition status, caries, and oral hygiene. The aim of this study was to compare the nutritional status, dental caries and oral hygiene of Islam Athirah elementary school representing high economic status and Bangkala III elementary school, representing low economic status. Samples were 120 children of aged 10-11 years. Study design was cross sectional study. The criteria of school chosen, was based on annual tuition fee, contribution fee, entrance school fee, and the presence of school operational aid (Dana BOS). Nutrition status was accessed using Z-score, dental caries using def-t index, and oral hygiene status accessed using OHI-S (DI-S and CI-S). Data of eating habitual, type of food, education and occupation of parents, frequency and method of tooth brushing were obtained from questionnaire. The results of this study showed no significant difference of nutritional status and oral hygiene status for both schools (Mann-Whitney, $p=0.281$ and 0.936), whereas significant difference was found for dental caries status between Islam Athirah and and Bangkala III elementary school $(p=0.01)$.
\end{abstract}

Key word: Nutritional status, dental caries, oral hygiene

\begin{abstract}
ABSTRAK
Status ekonomi berpengaruh terhadap beberapa aspek kehidupan, termasuk status gizi, karies gigi, dan oral hygiene seseorang. Penelitian ini bertujuan untuk membandingkan status gizi, karies gigi dan oral hygiene di SD Islam Athirah yang mewakili status ekonomi tinggi, dan SD Bangkala III yang mewakili status ekonomi rendah, di Makassar. Sampel adalah murid berusia 10-11 tahun, sebanyak 120 anak. Desain penelitian adalah cross sectional study. Pemilihan SD didasarkan kriteria besarnya pembayaran SPP/tahun, sumbangan komite, pembayaran uang masuk sekolah, dan ada tidaknya dana bantuan operasional sekolah (BOS). Status gizi diukur dengan z-score dan pengukuran kadar $\mathrm{Hb}$. Karies gigi diukur dengan menggunakan indeks dmf-t, dan oral hygiene diukur dengan menggunakan OHI-S (DI-S dan CI-S). Data tentang kebiasaan makan, jenis makanan, pendidikan dan pekerjaan orang tua serta frekuensi dan cara menyikat gigi diperoleh dari kuisioner. Simpulan penelitian ini menunjukkan bahwa tidak ada perbedaan bermakna status gizi dan oral hygiene pada kedua sekolah tersebut (Mann-Whitney, $\mathrm{p}=0,281$ dan $0,936)$, sedangkan untuk status karies terdapat perbedaan yang bermakna $(\mathrm{p}=0,001)$.

Kata kunci: Status gizi, karies, oral hygiene
\end{abstract}

Koresponden: Nurlindah Hamrun, Bagian Biologi Oral, Fakultas Kedokteran Gigi Universitas Hasanuddin, Jl. Perintis Kemerdekaan Km.10, Makassar, Indonesia 


\section{PENDAHULUAN}

Tingkat sosial ekonomi mempengaruhi kemampuan keluarga untuk mencukupi kebutuhan gizi, pemilihan macam makanan tambahan, kebiasaan hidup sehat, kualitas sanitasi lingkungan, dan seringnya seseorang menderita penyakit infeksi. Gizi buruk merupakan masalah yang timbul akibat kekurangan gizi yang mengancam masyarakat berstatus ekonomi rendah. $^{1}$

Gizi yang baik merupakan hal yang perlu untuk kesehatan fisik. Gizi juga memegang peranan penting dalam perkembangan dan pertahanan kesehatan mulut, terutama gigi dan gusi. Kondisi sehat atau tidak sehatnya gigi dan gusi dapat mempengaruhi asupan makanan. Pada penderita dengan karies gigi, sering terjadi gangguan asupan zat makanan yang merupakan faktor penyebab kurangnya gizi, sehingga dapat menyebabkan menurunnya fungsi biologis tubuh atau malnutrisi. ${ }^{2}$ Berdasarkan temuan-temuan dari penelitian cross-sectional yang melibatkan 1776 anak-anak Peru yang berusia antara 1 sampai 13 tahun, dan penelitian longitudinal yang melibatkan 209 anak, disimpulkan bahwa satu episode malnutrisi sedang pada tahun pertama kehidupan dihubungkan dengan peningkatan insiden timbulnya karies pada gigi sulung dan gigi permanen pada kehidupan selanjutnya. Karies gigi rahang atas anterior atau karies botol adalah penyakit gigi utama yang berhubungan dengan gizi yang ditemukan pada anak kecil. $^{3}$

Salah satu penyebab karies adalah diet, terutama sukrosa yang sifatnya sangat kariogenik. Kariogenitas makanan tergantung pada beberapa faktor, misalnya konsentrasi sukrosa, sifat perlekatan makanan pada permukaan gigi, kecepatan pembersihan rongga mulut, kualitas pembersihan, tekstur dan sifat campuran makanan, pengunyahan dan $\mathrm{pH}$ makanan itu sendiri. Selain faktor diet yang berpengaruh dalam proses karies adalah mikroorganisme, host dan waktu. ${ }^{4}$

Berdasarkan Survei Kesehatan Rumah Tangga (SKRT) pada tahun 1995, karies gigi merupakan penyakit masyarakat yang diderita oleh $90 \%$ penduduk Indonesia, yang bersifat progresif bila tidak dirawat/diobati sehingga akan makin parah, dan bersifat irreversible. Di negara-negara maju prevalensi karies gigi terus menurun, sedangkan di negara-negara berkembang termasuk Indonesia ada kecenderungan terjadi kenaikan prevalensi penyakit tersebut. Selain masalah karies, oral hygiene juga merupakan salah satu masalah penting dalam rongga mulut. Oral hygiene yang baik menggambarkan keadaan kesehatan umum yang baik pula, sebaliknya oral hygiene yang buruk menggambarkan kondisi kesehatan yang buruk. $^{5}$

Penulisan artikel ini bertujuan untuk melaporkan hasil penelitian mengenai gambaran status gizi, karies gigi, dan oral hygiene anak usia 10-11 tahun di SD Islam Athirah dan SD Bangkala III, dan perbedaan status gizi, karies gigi dan oral hygiene anak usia 10-11 tahun di SD Islam Athirah dan SD Bangkala III di Makassar.

\section{BAHAN DAN METODE}

Penelitian ini dilaksanakan pada tanggal 6 sampai 9 Desember 2006, yang bertempat di dua sekolah dasar di kota Makassar. Dipilih SD Islam Athirah yang mewakili SD dengan status ekonomi tinggi dan SD Bangkala III dengan status ekonomi lemah. Pemilihan sekolah dasar didasarkan pada kriteria besarnya pembayaran SPP/tahun, sumbangan komite, pembayaran uang masuk sekolah dan ada atau tidaknya dana bantuan operasional sekolah (BOS). Subjek 
penelitian adalah murid-murid sekolah dasar berumur 10-11 tahun, yang bersekolah di SD Islam Athirah dan SD Bangkala III Makassar. Desain penelitian ini adalah crossed sectional study.

Kepada seluruh sampel dilakukan pemeriksaan gigi dan mulut, yang meliputi pemeriksaan karies dengan menggunakan indikator dmf-t (decayed, missing, filled-tooth), dan pemeriksaan tingkat kebersihan mulut dengan menggunakan indeks OHI-S yang terdiri dari DI-S dan CI-S. Penentuan status gizi diukur dengan menggunakan z-score berdasarkan berat badan per umur, tinggi badan per umur, berat badan per tinggi badan, lingkar lengan atas per umur dan pengukuran kadar hemoglobin $(\mathrm{Hb})$. Data tentang penilaian kebiasaan makan, jenis makanan, frekuensi, cara menyikat gigi, pendidikan dan pekerjaan orang tua diperoleh melalui kuisioner.

\section{HASIL PENELITIAN}

Pada gambar 1 yang memperlihatkan status gizi anak-anak SD Islam Athirah dan anak-anak SD Bangkala III, murid dengan status gizi baik ditemukan lebih banyak di SD Islam Athirah sebanyak 36 murid (60,0\%), sedangkan murid dengan status gizi buruk ditemukan lebih banyak di SD Bangkala III, sebanyak 6 orang $(10,0 \%)$.

Pada gambar 2 yang menunjukkan perbandingan tingkat karies murid SD Islam Athirah dan murid SD Bangkala III, terlihat perbedaan yang paling menonjol adalah pada status karies sangat rendah, yaitu murid SD Islam Athirah sebanyak 38 orang $(63,3 \%)$ dan di SD Bangkala III sebanyak 15 anak (25,0\%). Pada status karies rendah, murid SD Bangkala III $(26,7 \%)$ jauh lebih tinggi dibanding murid SD Islam Athirah (10,0\%). Begitu pula untuk status karies sedang dan tinggi, SD Islam Athirah lebih rendah dibanding SD Bangkala III.

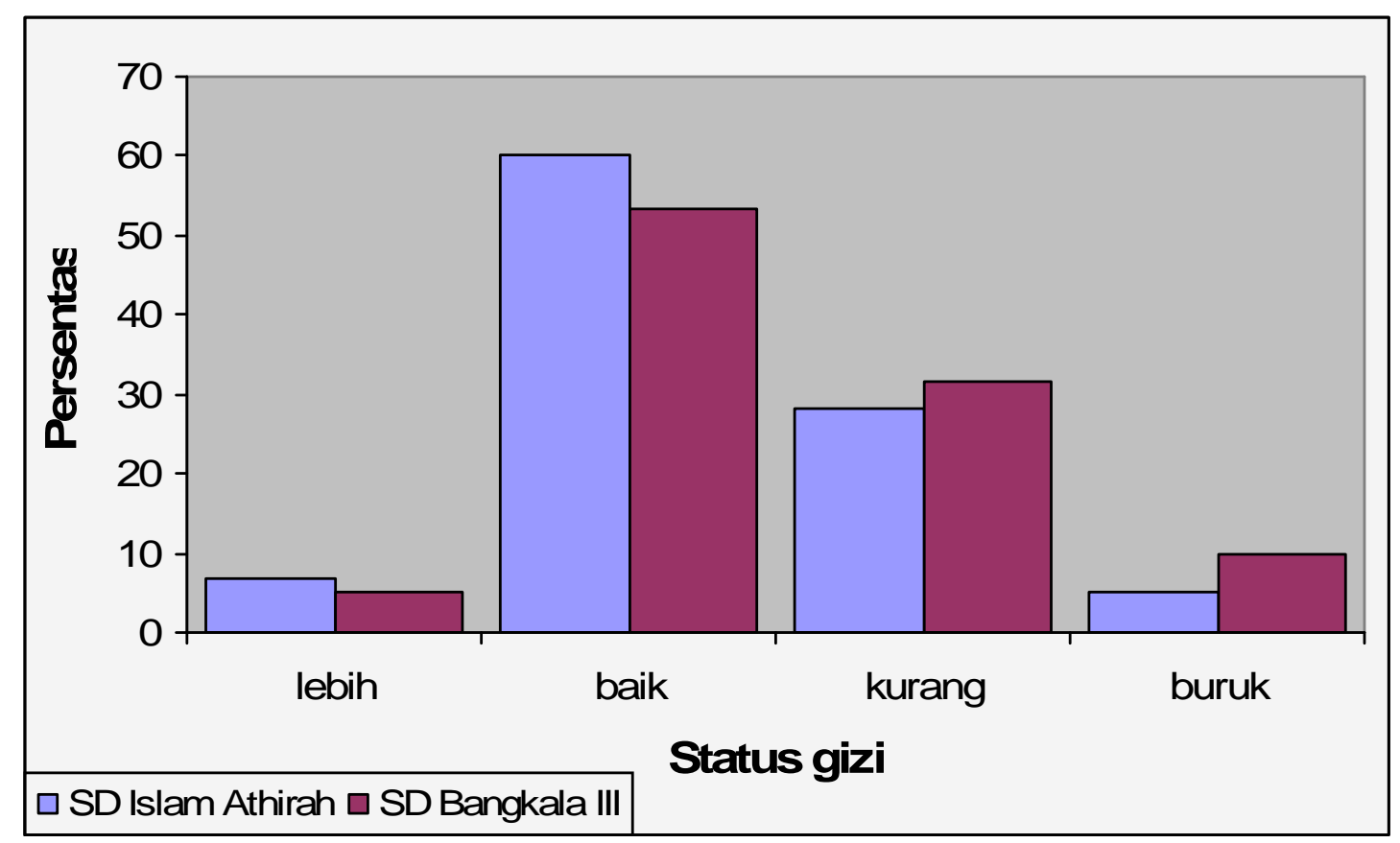

Gambar 1. Perbandingan status gizi murid SD Islam Athirah dan SD Bangkala III $(\mathrm{p}=$ 0,281). (Uji Mann-Whitney p < 0,05) 


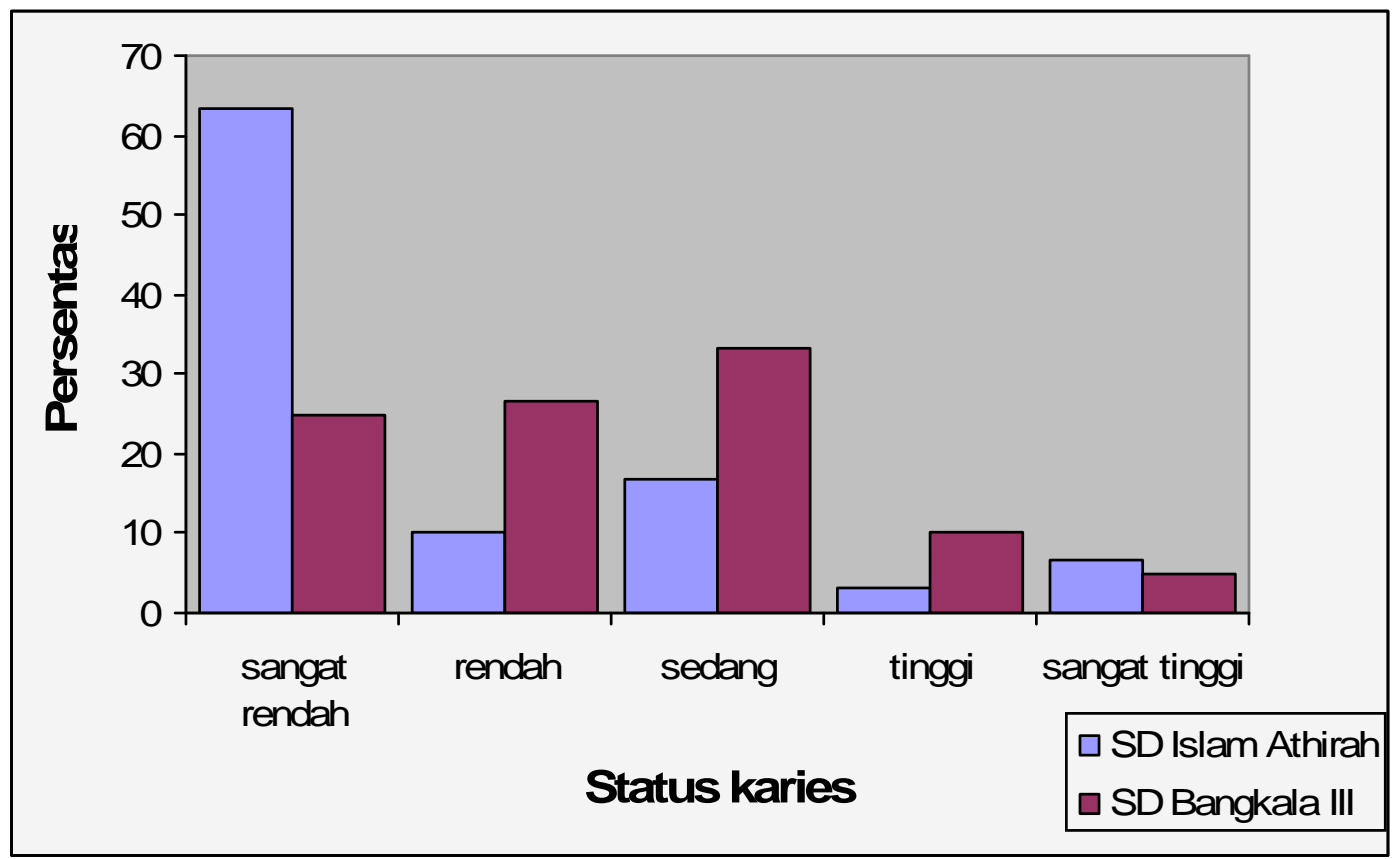

Gambar 2. Perbandingan status karies murid SD Islam Athirah dan murid SD Bangkala III $(\mathrm{p}=0,001)$. (Uji Mann-Whitney $p<0,05)$

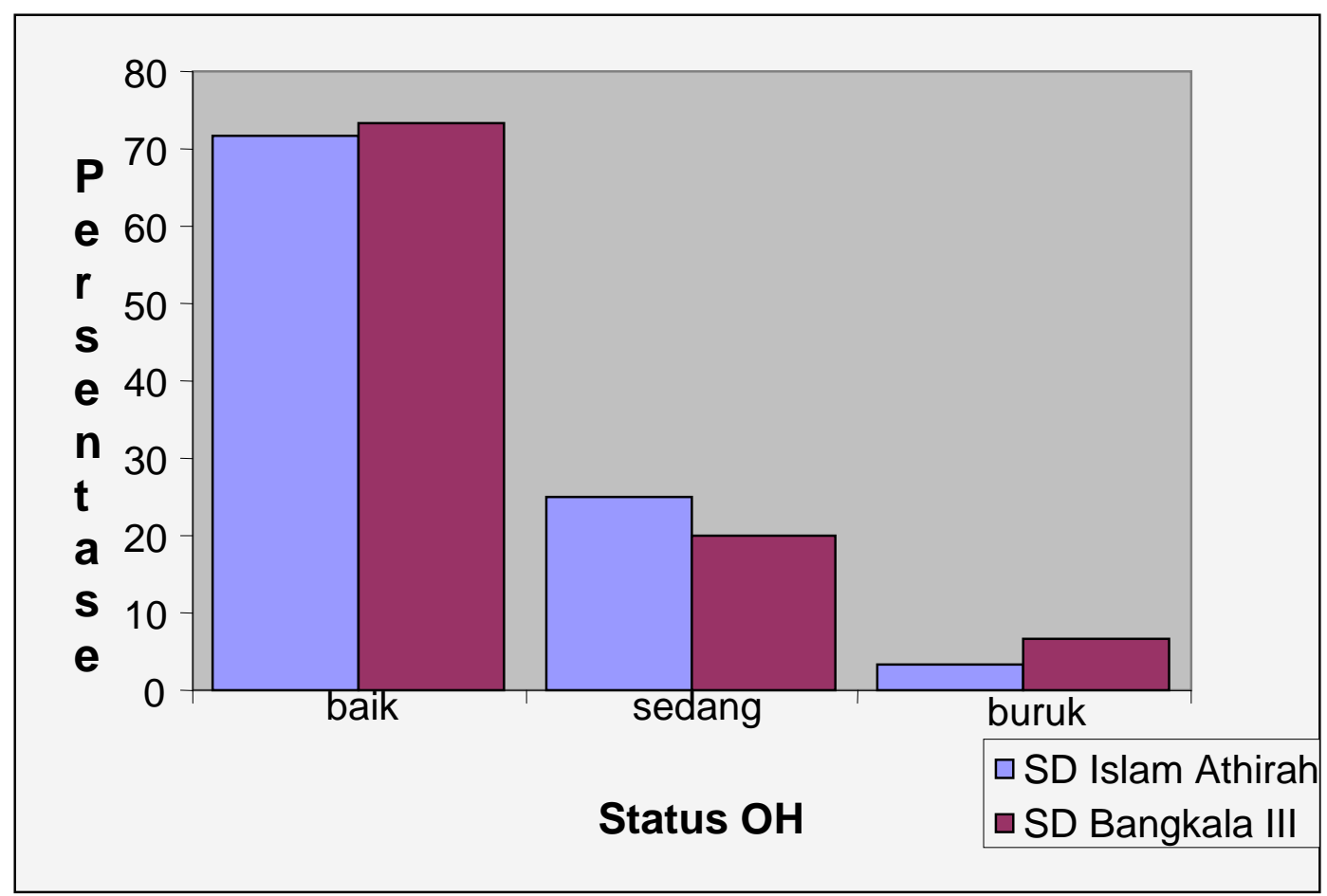

Gambar 3. Perbandingan status OH murid SD Islam Athirah dan murid SD Bangkala III ( $\mathrm{p}=0,936)$. (Uji Mann-Whitney $p<0,05)$

Pada gambar 3 yang menggambarkan status oral hygiene murid SD Islam Athirah dan murid SD Bangkala III, terlihat bahwa status oral hygiene murid kedua sekolah tidak jauh berbeda.
Oral hygiene baik dan sedang ditemukan lebih banyak pada murid SD Islam Athirah dibandingkan pada murid SD Bangkala III. Pada status $\mathrm{OH}$ buruk, murid SD Bangkala III 
mempunyai frekuensi yang lebih tinggi dibandingkan murid SD Islam Athirah.

\section{PEMBAHASAN}

Penentuan status gizi sangat dipengaruhi oleh asupan makanan yang masuk ke dalam tubuh. Anak-anak dengan asupan zat gizi yang cukup akan memiliki kesehatan umum yang baik karena zat-zat gizi yang diperlukan, seperti karbohidrat, protein, kalsium, fosfor, magnesium dan fosfor tercukupi. Masyarakat dengan status ekonomi menengah ke bawah kadang-kadang tidak mampu memenuhi kebutuhan asupan gizi tersebut sehingga sangat berpengaruh pada kondisi kesehatannya.

Karbohidrat yang terdapat pada tepungtepungan dan gula murni besar pengaruhnya dalam pembentukan karies gigi. Sebaliknya sumber karbohidrat yang banyak mengandung serat seperti pada buah dan sayur bermanfaat dalam membersihkan gigi. ${ }^{6}$

Kalsium merupakan bahan utama untuk pembentukan dentin dan email. Asupan kalsium yang kurang pada masa pertumbuhan dapat mengganggu pertumbuhan gigi. Hal tersebut juga berlaku untuk fosfor. Magnesium berfungsi mencegah kerusakan gigi dengan cara menahan kalsium di dalam email gigi. Sedangkan fluor berperan dalam proses mineralisasi dan pengerasan email gigi. ${ }^{6}$

Hasil penelitian menunjukkan bahwa status gizi murid SD Islam Athirah dan status gizi murid SD Bangkala III tidak jauh berbeda. Dengan uji statistik diperoleh nilai $p=0,281$. Dari hasil tersebut dapat disimpulkan bahwa tidak ada perbedaan yang signifikan antara status gizi siswasiswi SD Islam Athirah dan SD Bangkala III. Hal ini mungkin disebabkan karena lokasi penelitian secara geografis yang hampir sama yaitu kota Makassar, distribusi air minum yang sebagian besar berasal dari sumber yang sama, jenis makanan yang dikonsumsi dan kebiasaan makan hampir sama, serta kultur sosial yang hampir tidak ada perbedaan.

Karies gigi juga disebut sebagai penyakit multifaktorial. Faktor-faktor yang berperan dalam proses terjadinya karies, antara lain proses dari ketahanan jaringan gigi, bakteri, sumber-sumber makanan seperti karbohidrat, faktor pelindung gigi seperti saliva, dan komponen-komponennya, serta waktu. Selain itu, terdapat pula faktor resiko luar yaitu usia, jenis kelamin, tingkat pendidikan, tingkat ekonomi, lingkungan, sikap, dan perilaku yang berhubungan dengan kesehatan gigi. Beberapa penelitian menunjukkan ada hubungan antara suku bangsa dengan prevalensi karies, keadaan sosial ekonomi, pendidikan, jenis makanan, pola makan, cara pencegahan karies, dan jangkauan pelayanan kesehatan gigi yang berbeda di setiap suku tersebut. ${ }^{7}$ Menurut American Academy of Pediatric Dentistry, penilaian risiko karies pada anak didasarkan atas tiga bagian besar indikator karies, yaitu kondisi klinik, karakteristik lingkungan, dan kondisi kesehatan umum. ${ }^{8}$

Dari hasil penelitian, didapatkan bahwa tingkat karies murid SD Islam Athirah dan murid SD Bangkala III memiliki perbedaan yang bermakna $(p=0,001)$. Hal ini mungkin disebabkan adanya perbedaan kondisi sosial ekonomi, pendidikan orang tua, jenis dan pola makan, dan perawatan gigi pada kedua sekolah tersebut. Dari aspek tersebut, SD Bangkala III dapat digolongkan status ekonomi menengah ke bawah dengan distribusi pekerjaan orang tua sebagai PNS dan mempunyai pekerjaan tetap sebanyak $33,3 \%$, buruh harian sebanyak $30 \%$, dan selebihnya sekitar 36,7\% tidak memiliki pekerjaan tetap. Sedangkan SD Islam Athirah merupakan sekolah dengan latar belakang sosial ekonomi 
menengah ke atas dengan distribusi pekerjaan orang tua $73,4 \%$ mempunyai pekerjaan tetap dan sekitar 26,6\% bekerja sebagai wiraswasta.

Beberapa peneliti melaporkan bahwa prevalensi karies lebih tinggi pada anak yang berasal dari status ekonomi rendah. American Academy of Pediatric Dentistry menyatakan bahwa status sosial ekonomi tinggi berisiko rendah terhadap terjadinya karies gigi, tetapi status ekonomi menengah dan rendah memiliki risiko yang lebih tinggi terhadap karies gigi. Hal ini disebabkan anak dari status ini memakan lebih banyak makanan yang bersifat kariogenik dan kurang konsumsi serat, rendahnya pengetahuan orang tua, dan jarang melakukan perawatan ke dokter gigi. ${ }^{8}$ Sumber lain, Wycoff menjelaskan bahwa ada hubungan antara keadaan sosial ekonomi dan prevalensi karies. Faktor yang mempengaruhi keadaan ini adalah pendidikan dan penghasilan yang berhubungan dengan diet, kebiasaan merawat gigi, dan lain-lain. ${ }^{9}$

The Centre for Disease Control and Prevention $(C D C P$ ) melaporkan bahwa karies gigi mungkin merupakan penyakit infeksi dengan prevalensi tertinggi pada anak-anak. Tingkat kejadian karies gigi 5 kali lebih tinggi dibanding penyakit asma dan 7 kali lebih tinggi dibanding demam pada anak. Lebih dari $40 \%$ anak-anak menderita karies pada saat mereka memasuki taman kanak-kanak. Anak-anak yang berasal dari keluarga ekonomi lemah dan tingkat pendidikan ibu yang rendah, dan mengkonsumsi makanan manis memiliki risiko karies 32 kali pada usia 3 tahun dibanding anak-anak yang tidak mempunyai faktor risiko. ${ }^{10}$

Mc Donald dkk melaporkan bahwa satu diantara empat anak Amerika lahir dalam kemiskinan. Tercatat bahwa anak-anak dan remaja yang hidup dalam kemiskinan menderita karies dua kali lebih banyak dibanding teman sebaya yang hidup lebih makmur dan bahwa penyakit mereka lebih banyak yang tidak mendapat perawatan. Laporan tersebut juga mengatakan bahwa meskipun pengurangan yang berkelanjutan terhadap karies gigi pada gigi permanen diperoleh, pravalensi karies pada gigi sulung dapat meningkat pada kelompok populasi yang sama. ${ }^{11}$

Jika ditinjau dari segi pendidikan sebagian besar orang tua siswa di SD Islam Athirah memiliki pendidikan minimal S1, sehingga tingkat pengetahuan dan kepedulian terhadap kesehatan juga tinggi. Hal ini sesuai dengan pernyataan Matram dalam artikelnya yang berjudul "penyakit gigi”, bahwa tingkat pendidikan memiliki hubungan dengan penyakit gigi. Sebanyak 63 persen penduduk Indonesia menderita karies yang tidak diobati dengan tingkat rata-rata 1,89 penyakit karies per orang. Persentase tersebut semakin menurun pada kelompok masyarakat yang pendidikannya semakin tinggi. ${ }^{12}$

Lebih lanjut Matram mengatakan bahwa berdasarkan data International Dental Journal tahun 2002, penyakit gigi dan mulut merupakan penyakit keempat yang paling mahal biaya penyembuhannya. Pengobatan penyakit gigi dan mulut berdasarkan data tersebut membutuhkan biaya hingga 3.513 dolar AS per 1000 anak. Anggaran tersebut melebihi anggaran kesehatan yang diperuntukkan bagi anak di negara-negara yang paling rendah pendapatan per kapitanya. Sebanyak $63 \%$ penduduk Indonesia menderita karies yang tidak diobati dengan tingkat rata-rata 1,89 penyakit karies per orang. ${ }^{12}$

Usia 10-11 tahun merupakan kelompok usia yang rentan terhadap karies. Anak-anak lebih cenderung suka terhadap makanan yang mengandung banyak gula, sedangkan gula merupakan sumber diet terbesar yang dapat menyebabkan karies. Kebiasaan makan diantara waktu makan (ngemil) juga sangat berpengaruh 
terhadap karies pada anak-anak. Hal ini sesuai dengan hasil penelitian yang menyatakan bahwa banyaknya asupan gula harian lebih besar hubungannya dibanding dengan frekuensi makan gula. Hubungan gula dalam snack dengan karies lebih besar dibanding total diet karena snack lebih sering dimakan dalam frekuensi tinggi dan makanan kariogenik yang sering dimakan di antara dua waktu makan mempunyai ciri-ciri $\mathrm{pH}$ rendah, mengandung gula tinggi dan lengket. Hampir semua anak menyukai anak makanan minuman kariogenik yang merupakan faktor risiko terhadap karies yang dimakan di antara dua waktu makan. Selain itu, anak-anak juga cenderung malas membersihkan rongga mulutnya sehingga dapat membentuk plak yang akhirnya menyebabkan karies. ${ }^{9}$

Tingkat kebersihan mulut murid-murid SD Islam Athirah dan SD Bangkala III tidak menunjukkan perbedaan yang bermakna $(\mathrm{p}=$ $0,936)$. Hal ini mungkin disebabkan pola makan dan pola hidup bersih termasuk cara menyikat gigi pada anak-anak usia 10-11 tahun hampir sama pada kedua sekolah ini. Anak-anak cenderung lebih menyukai konsumsi makanan ringan dengan rasa manis yang tinggi, kaya karbohidrat, lunak dan lengket, dan memiliki kesadaran dan pengetahuan yang rendah untuk membersihkan giginya. Hal ini sesuai dengan data hasil kuisioner yang menunjukkan persentase yang tinggi dan hampir sama pada kedua sekolah.

\section{SIMPULAN}

Dari hasil penelitian ini dapat disimpulkan bahwa status karies SD Bangkala III lebih tinggi dari pada SD Islam Athirah. Sedangkan status gizi dan status oral hygiene SD Islam Athirah dan SD Bangkala III sama karena tidak didapatkan perbedaan yang bermakna.

\section{SARAN}

Diharapkan pada penelitian selanjutnya menggunakan karakteristik sampel yang lebih beragam seperti kultur sosial yang berbeda, kebiasaan dan pola hidup yang berbeda, jumlah sampel yang lebih banyak, dan variabel lainnya yang dapat mempengaruhi status gizi, kejadian karies dan oral hygiene pada anak usia sekolah.

\section{DAFTAR PUSTAKA}

1. Ilyas M. Perbedaan status karies gigi pada pasien pengguna jaringan pengaman sosial dengan non jaringan pengaman sosial. 2002. J Med Nus 2002; 23 (2):

2. Anderson J, Brown L. Dental nutrition. Available at: http://www.dentalnutrition @ google.com. Accessed on January 2007.

3. Anonim. Position of the American diet association: oral health and nutrition. Available at: http://ww.dentalnutrition @ google.com. Accessed on February 2007.

4. Supartinah. Pengaruh makanan sehari-hari terhadap pertumbuhan Streptococcus alpha dan Staphylococcus pada rongga mulut anak. Majalah Ilmu Kedokteran Gigi Indonesia 1999; 1 (2):

5. Octiara E, Roesnawi Y. Karies gigi, oral hygiene dan kebiasaan membersihkan gigi pada anak-anak panti Karya Pungai di Binjai. Dentika Dent J 2001; 6 (1):

6. Siswono. Pengaruh nutrisi dan gaya hidup. 2007. Available at: http://www.gizinet @ google.com. Accessed on Januari 2008.

7. Nurlaila, Djoharnas H, Darwita R. Hubungan status gizi dengan karies gigi pada muridmurid di sekolah dasar kec.Karangutu. IJD 2005; 12 (1):

8. Angela A. Pencegahan primer pada anak yang berisiko karies tinggi. 2007. Available at: http://www.risikokaries@google.com. Accessed on: Januari 2008.

9. Anonim. Pengetahuan dan praktek ibu hubungannya dengan frekuensi konsumsi makanan jajanan kariogenik dan status karies gigi pada anak usia 2-4 tahun di Kel. Tegalsari, Kec. Candisari Kota Semarang. 
2008. Available at : http://www.penelitian @ google.com. Accessed on Januari 2008.

10. Weiss PA. Oral health risk assessment timing and establishiment of the dental home. J Am Acad Pediatrics 2005; 11 (08).

11. Mc Donald R E, Avery D R, Dean J A.
Dentistry for the child and adolescent. $8^{\text {th }}$ ed. Missouri: Mosby; 2004.

12. Anonim. Penyakit gigi, 77 persen orang Indonesia malas sikat gigi. 2007. Available at: http://www.kariesgigi@yahoo.com. Accessed on Januari 2008. 